\title{
ADAPTATION AND VALIDATION OF THE CAMBRIDGE PULMONARY HYPERTENSION OUTCOME REVIEW (CAMPHOR) FOR CROATIA
}

\author{
Ana Hećimović ${ }^{1}$, Alice Heaney ${ }^{2}$, Stephen P. McKenna ${ }^{2}$, Latinka Basara ${ }^{1}$, \\ Marko Jakopović ${ }^{1,3}$, Andrea Vukić Dugac ${ }^{1,3}$, Gzim Redžepi ${ }^{1}$, Cecilija Rotim ${ }^{4}$, \\ Miroslav Samaržija ${ }^{1,3}$, Nataša Jokić-Begić ${ }^{5}$ and Sanja Popović-Grle ${ }^{1,3}$ \\ ${ }^{1}$ Department for Lung Diseases, Zagreb University Hospital Centre, Zagreb, Croatia; \\ ${ }^{2}$ Galen Research, Manchester, UK; ${ }^{3}$ School of Medicine, University of Zagreb, Zagreb, Croatia; \\ ${ }^{4}$ Dr. Andrija Štampar Teaching Institute of Public Health, Zagreb, Croatia; \\ ${ }^{5}$ Faculty of Humanities and Social Science, University of Zagreb, Zagreb, Croatia

\begin{abstract}
SUMMARY - Pulmonary hypertension (PH) is a chronic disease which severely impairs quality of life (QoL). The Cambridge Pulmonary Hypertension Outcome Review (CAMPHOR) is the first disease-specific tool to assess patient-reported symptoms, functioning and $\mathrm{QoL}$ in $\mathrm{PH}$ patients. The aim of this study was to adapt and validate the CAMPHOR for use in Croatia. The adaptation process involved three stages: translation (bilingual and lay panel), cognitive debriefing interviews with patients and psychometric validation. For the latter stage, a postal survey was conducted with 50 patients to examine the reliability and validity of the adapted scale. All three scales of the Croatian CAMPHOR demonstrated excellent internal consistency $($ Symptoms $=0.93$; Activity limitations $=$ 0.94; $\mathrm{QoL}=0.92)$ and test-retest reliability correlations (Symptoms $=0.90 ;$ Activity limitations $=$ 0.95; $\mathrm{QoL}=0.90$ ). Predicted correlations with the SF-36 scales provided evidence for construct validity of the CAMPHOR scales. Evidence for known group validity was shown by the ability of the scales to distinguish between participants based on patient-perceived general health and disease severity. The Croatian version of the CAMPHOR is a valid and reliable tool for use in clinical routine and clinical research.
\end{abstract}

Key words: Hypertension, pulmonary; Quality of life; Croatia; Reproducibility of results; Surveys and questionnaires

\section{Introduction}

Pulmonary hypertension $(\mathrm{PH})$ is an umbrella term which describes the pathophysiological state characterized by elevation of the pulmonary artery pressure (PAP). It is diagnosed when the mean PAP is $\geq 25 \mathrm{~mm}$ $\mathrm{Hg}$ at rest ${ }^{1}$. The increase in pressure is progressive and leads to right ventricular failure ${ }^{2}$. The main symptoms of $\mathrm{PH}$ in the initial stages are nonspecific, such as ex-

Correspondence to: Ana Hećimović, MD, Zagreb University Hospital Centre, Department for Lung Diseases, Jordanovac 104, HR-10000 Zagreb, Croatia

E-mail: anahecimovic1978@gmail.com

Received September 19, 2018, accepted February 21, 2019 ertional dyspnea, fatigue, angina, syncope or abdominal distension. Disease-specific pharmacotherapy can improve patient prognosis, but no cure is possible for primary $\mathrm{PH}^{3}$.

Traditionally, large-scale clinical trials in $\mathrm{PH}$ have relied on clinical outcomes as endpoints ${ }^{4}$, but these are impractical in everyday practice. The six-minute walk test (6MWT) has often been used as a primary endpoint, yet the test is not capable of providing an accurate reflection of the patient experience of living with $\mathrm{PH}^{5}$.

More recently, clinical studies in $\mathrm{PH}$ have included health-related quality of life (HRQL) instruments such as the 36-item Short-Form Health Survey $(\mathrm{SF}-36)^{6-9}$, 
EuroQoL ${ }^{9,10}$, and Nottingham Health Profile ${ }^{11}$. These measures focus on the measurement of symptoms and functioning ${ }^{12}$. However, generic instruments are of limited value as they are likely to miss issues pertinent to specific patient populations and include questions that are not relevant to different groups of respondents ${ }^{13}$. Furthermore, these instruments demonstrate poor responsiveness ${ }^{14-16}$.

Pulmonary hypertension has a significant impact on the lives of patients, and $\mathrm{PH}$-specific outcome measures are required to determine these effects accurately. $\mathrm{PH}$ symptoms such as exertional dyspnea and fatigue have a major impact on physical activity, functioning and working ability, which affects HRQL ${ }^{17}$. Associated conditions such as systemic sclerosis and side effects of pharmacological treatment (e.g., subcutaneous or parenteral prostacyclin) also affect HRQL of pulmonary arterial hypertension (PAH) patients. There is also the psychological impact of $\mathrm{PAH}$, which includes feelings of social isolation. Approximately half of patients with PAH have symptoms of anxiety and about one-third experience symptoms of depres$\operatorname{sion}^{18}$.

The Cambridge Pulmonary Hypertension Outcome Review (CAMPHOR) has been developed to assess both HRQL and quality of life (QoL) in patients diagnosed with $\mathrm{PH}^{19}$. Consequently, it provides an overall picture of how $\mathrm{PH}$ affects the lives of $\mathrm{pa}^{-}$ tients. The CAMPHOR is a needs-based outcome measure ${ }^{20}$. Its underlying theory is that QoL represents the capacity of individuals to fulfill their basic human needs. Over 20 disease-specific measures have been developed that apply the needs-based model.

The CAMPHOR was developed using qualitative interviews conducted with $\mathrm{PH}$ patients. This ensured that only the most appropriate and relevant concerns of the patients rather than health professionals were included in the measure. The CAMPHOR has been shown to have excellent psychometric properties, maximizing its ability to detect changes in $\mathrm{QoL}^{21}$. Following the development of the CAMPHOR, two other PAH specific patient-reported outcome measures have been developed: emPHasis-10 questionnaire and Pulmonary Arterial Hypertension-Symptoms and Impact Questionnaire (PAH-SYMPACT) ${ }^{\circledR 22,23}$. These measures assess patient perceived health status but do not collect information on QoL. Therefore, the CAMPHOR is the only PAH specific measure that integrates the assessment of true QoL.
Prior to this study, the CAMPHOR was not available in Croatian. We report on the adaptation of the CAMPHOR into Croatian and its subsequent validation. It was intended that the adaptation would produce a reliable and valid outcome measure for use in $\mathrm{PH}$ studies in Croatia.

\section{Patients and Methods}

Three stages were employed in adapting the CAMPHOR:

- translation,

- interviews with relevant patients, and

- psychometric validation.

Patients were invited to take part in the interviews and postal validation survey if they were aged at least 18 years, were monolingual Croatian speakers, met the World Health Organization (WHO) definition of $\mathrm{PH}$, and could understand and provide written informed consent. Patients were recruited from the $\mathrm{Za}$ greb University Hospital Centre in Zagreb. Following the Ethics Committee approval, all patients provided their written informed consent prior to inclusion in the study.

\section{Stage 1: Translation}

The CAMPHOR was translated into Croatian using two separate translation panels ${ }^{24}$. Firstly, a bilingual panel was held. This consisted of Croatian individuals whose first language was Croatian and who were also fluent in English. The task of this panel was to work as a team to translate the UK English version of the CAMPHOR into Croatian. The focus was on producing conceptual equivalence and a translation that would be comprehensible and acceptable to Croatian respondents. If the group differed on the most appropriate wording for an item, alternative potential translations were sent to a second panel.

Secondly, a lay panel was held, consisting of six monolingual Croatian individuals who were less well educated. This panel was employed to ensure that the items sounded 'natural' and were simple enough for a range of potential respondents to understand. The instructions and items translated by the bilingual panel were presented to members of the lay panel and they were asked to check on ease of understanding, and whether the wording was appropriate. Where alterna- 
tive translations were presented, participants selected the most acceptable one. Both panels were led by the same Croatian researcher.

\section{Stage 2: Cognitive debriefing interviews}

Ten face to face interviews were conducted with relevant patients to determine the face and content validity of the translated scale. The respondents filled in the CAMPHOR in front of the interviewer before answering a series of questions about its acceptability and comprehensiveness.

\section{Stage 3: Psychometric validation survey}

The reliability and validity of the Croatian CAMPHOR was tested by means of a postal survey. PH patients were invited to take part in the survey. Demographic data and illness information were collected from eligible patients attending the outpatient clinic for pulmonary disease at the hospital. At the first administration (Time 1), the Croatian CAMPHOR and the Croatian version of the SF- $36^{25}$ were included in the postal survey. Respondents who completed and returned both questionnaires were administered the CAMPHOR again approximately two weeks later (Time 2), to assess reproducibility.

\section{Measures}

The CAMPHOR has three individual scales: Symptoms (25 items), Activities (15 items) and QoL (25 items) (Table 1). The Symptoms scale employs "Yes" /"No" format that measures the presence of $\mathrm{PH}$ symptoms (from 0 to 25). A higher score indicates higher symptomatology. The Activities scale assesses the extent to which the patient's daily functioning is affected by PH. Each item in the scale has three response options: "Able to do on own without difficulty", "Able to do on own with difficulty", and "Unable to do on own". Each item is scored 0 to 2, giving a total score of 0 to 30 . Poor physical functioning is indicated by high scores. The QoL scale uses a "True"/"Not true" response format that indicates that $\mathrm{PH}$ interferes with need fulfillment. Again, a high score indicates poorer QoL.

\section{The 36-item Short-Form Health Survey (SF-36)}

The SF-36 is a generic HRQL measure containing 36 items falling into eight sections (physical function-
Table 1. Example CAMPHOR items and Croatian translation

\begin{tabular}{|l|l|}
\hline $\begin{array}{l}\text { Symptoms } \\
\text { scale }\end{array}$ & $\begin{array}{l}\text { I get tired very quickly } \\
\text { (Croatian: Jako brzo se umaram) } \\
\text { I get breathless without doing anything } \\
\text { (Croatian: Nedostaje mi daha i kad ne } \\
\text { radim ništa) }\end{array}$ \\
\hline $\begin{array}{l}\text { Activities } \\
\text { scale }\end{array}$ & $\begin{array}{l}\text { Stand for a short time } \\
\text { (Croatian: Kratko stajati) } \\
\text { Lift heavy items } \\
\text { (Croatian: Podizati teške predmete) }\end{array}$ \\
\hline $\begin{array}{l}\text { Quality } \\
\text { of Life scale }\end{array}$ & $\begin{array}{l}\text { It feels like my body has let me down } \\
\text { (Croatian: Osjećam kao da me tijelo } \\
\text { iznevjerilo) } \\
\text { I feel as if I am a burden to people } \\
\text { (Croatian: Osjećam kao da sam teret } \\
\text { drugim ljudima) }\end{array}$ \\
\hline
\end{tabular}

ing, social functioning, physical role limitations, emotional role limitations, mental health, energy, pain, general health and health transition). Each section is scored from 0 to 100 , but for this measure, a higher score indicates better HRQL.

\section{Statistical analyses}

Descriptive statistics: Median and inter-quartile range $[\mathrm{IQR}]$ ) scores were calculated for CAMPHOR responses, together with floor and ceiling effects.

Internal consistency: Internal consistency was assessed using Cronbach's alpha, with values below 0.70 indicating that it would be inappropriate to sum item scores $^{26}$.

Reproducibility: Spearman's rank correlation coefficient was calculated to establish the test-retest reliability of the CAMPHOR. This estimate of reproducibility should be 0.85 or above ${ }^{27}$.

Convergent validity: Convergent validity was determined by correlating scores on the SF-36 sections with those on the CAMPHOR scales. It was expected that QoL scores would be moderately highly correlated with the HRQL scores, particularly energy level and physical limitations.

Known group validity: Known group validity was assessed using Mann-Whitney U tests. These examined whether the CAMPHOR was able to show meaningful differences in score between respondents who differed by self-perceived general health ('very 
good or good' and 'fair or poor') and disease severity ('mild or moderate' and 'quite severe or very severe').

Scores of patients who differed by age (below versus above median age) and gender were also examined for differences in CAMPHOR scores. As the data collected were at the ordinal level of measurement, nonparametric statistical tests were employed. The Statistical Package for the Social Sciences version 23.0 was used on analyses ${ }^{28}$.

\section{Results}

\section{Stage 1: Translation}

Bilingual panel: Two males and four females participated in the bilingual panel. They were aged between 22 and 35 years. The panel found little difficulty in producing translation of the CAMPHOR, with most items considered straightforward. For some items, direct translation of the item was not appropriate. For example, for the item: 'I feel worn out', the bilingual panel suggested the translation 'I feel drained/ spent' to capture the intended meaning of the item.

Lay panel: One male and five females made up the lay panel. Their ages ranged from 30 to 76 years. Changes were made to the translations where the lay panel felt the item could be expressed in more commonly used language. For example, 'I get out of breath when I stand up' from the Symptoms scale was improved by the lay panel. The phrase 'kad ustanem ostanem bez daha' was replaced with 'kad ustanem ponestane mi daha' in the lay panel, as the latter was considered a more natural expression in Croatian.

\section{Stage 2: Cognitive debriefing interviews}

Ten cognitive debriefing interviews were performed (seven female; mean age 39 years). Eight patients had idiopathic pulmonary arterial hypertension and two had pulmonary hypertension resulting from congenital heart disease. Interviewees completed the questionnaire between 6 and 11 minutes $($ mean $=8.8$ minutes).

The mean time taken to complete the CAMPHOR was 8.8 (range 6 to 11) minutes. Respondents considered the questionnaire to be clear, comprehensible and relevant. Due attention was paid to three items in the cognitive debriefing interviews (CDIs), in which both the bilingual and lay panel translations were presented
Table 2. Demographic and disease information $(N=50)$

\begin{tabular}{|c|c|c|}
\hline Age & Years & \\
\hline Mean (SD) & $52.8(14.4)$ & \\
\hline Median (IQR) & $52.2(43.1-65.7)$ & \\
\hline Range & $24.1-78.2$ & \\
\hline Gender & n & $\%$ \\
\hline Male & 15 & 30 \\
\hline Female & 35 & 70 \\
\hline Marital status & & \\
\hline Married/living as married & 30 & 60 \\
\hline Divorced & 4 & 8 \\
\hline Widowed & 2 & 4 \\
\hline Single & 14 & 28 \\
\hline Work status & & \\
\hline Working full-time & 6 & 12 \\
\hline Homemaker & 2 & 4 \\
\hline Retired & 29 & 58 \\
\hline Long-term sick leave & 3 & 6 \\
\hline Unemployed & 7 & 14 \\
\hline Student & 2 & 4 \\
\hline Other & 1 & 2 \\
\hline Diagnosis & & \\
\hline Idiopathic $\mathrm{PAH}$ & 13 & 26 \\
\hline $\begin{array}{l}\text { PAH due to congenital } \\
\text { heart disease }\end{array}$ & 14 & 28 \\
\hline $\begin{array}{l}\text { PAH due to connective } \\
\text { tissue disease }\end{array}$ & 10 & 20 \\
\hline $\begin{array}{l}\text { Chronic thromboembolic } \\
\text { pulmonary hypertension }\end{array}$ & 13 & 26 \\
\hline $\begin{array}{l}\text { Patient-perceived disease } \\
\text { severity }\end{array}$ & & \\
\hline Mild & 5 & 10 \\
\hline Moderate & 21 & 42 \\
\hline Quite severe & 21 & 42 \\
\hline Very severe & 2 & 4 \\
\hline Missing & 1 & 2 \\
\hline $\begin{array}{l}\text { Patient-perceived general } \\
\text { health }\end{array}$ & & \\
\hline Very good & 2 & 4 \\
\hline Good & 13 & 26 \\
\hline Fair & 21 & 42 \\
\hline Poor & 14 & 28 \\
\hline
\end{tabular}

$\mathrm{SD}=$ standard deviation; $\mathrm{IQR}=$ interquartile range; $\mathrm{PAH}=$ pulmonary arterial hypertension 
Table 3. Questionnaire descriptive statistics

\begin{tabular}{|l|l|l|l|l|l|}
\hline & $\mathrm{n}$ & Median (IQR) & Min - Max & \% scoring minimum & \% scoring maximum \\
\hline Time 1 & & & & & \\
CAMPHOR Symptoms & 47 & $9(4-13)$ & $0-24$ & 6 & 0 \\
CAMPHOR Activities & 50 & $8(4-13)$ & $1-25$ & 0 & 0 \\
CAMPHOR QoL & 48 & $5(2-13)$ & $0-21$ & 13 & 0 \\
\hline SF-36 sections (Time 1) & & & & & \\
Physical functioning & 48 & $55(30-69)$ & $0-90$ & 6 & 0 \\
Physical role limitations & 50 & $25(0-100)$ & $0-100$ & 36 & 32 \\
Bodily pain & 50 & $62(41-100)$ & $12-100$ & 0 & 28 \\
General health & 48 & $35(25-59)$ & $5-87$ & 0 & 0 \\
Vitality & 50 & $53(40-70)$ & $5-90$ & 0 & 0 \\
Social functioning & 49 & $63(50-88)$ & $0-100$ & 4 & 14 \\
Emotional role limitations & 50 & $100(33-100)$ & $0-100$ & 22 & 2 \\
Emotional well-being & 50 & $68(51-77)$ & $24-100$ & 0 & 4 \\
\hline Time 2 & & & & & 0 \\
CAMPHOR Symptoms & 49 & $11(4-17)$ & $0-25$ & 6 & 2 \\
CAMPHOR Activities & 50 & $10(5-14)$ & $0-29$ & 2 & 15 \\
CAMPHOR QoL & 48 & $7(2-17)$ & $0-25$ & & 0 \\
\hline
\end{tabular}

$I Q R$ = interquartile range; CAMPHOR = Cambridge Pulmonary Hypertension Outcome Review; QoL = quality of life

to patients for consideration. For two of the items, interviewees felt that the translation generated by the lay panel sounded more natural in Croatian. For the item 'My condition limits the places I can go', interviewees preferred the bilingual panel's translation for clarity and understanding.

\section{Stage 3: Psychometric validation}

All the patients invited agreed to participate in the postal validation survey $(n=50)$. Table 2 provides demographic information on the sample and ratings of perceived disease severity and general health. Most respondents were female and married or living as married. More than half the sample were retired. Most patients perceived their disease severity to be 'moderate' or 'quite severe' and rated their general health as 'fair'.

\section{Descriptive statistics}

Table 3 shows scores obtained on the outcome measures. Large proportions of respondents scored at the minimum or maximum on the physical role limitations and emotional role limitations sections of the
SF-36. The pain section also demonstrated ceiling effects, indicating that these subscales are not well targeted to $\mathrm{PH}$ patients.

\section{Internal consistency and reproducibility}

Alpha coefficients and test-retest reliability for the CAMPHOR are shown in Tables 4 and 5, respectively. All values achieved were well above the required values.

Table 4. Cronbach's alpha coefficients

\begin{tabular}{|l|l|l|}
\hline & Time 1 & Time 2 \\
\hline Symptoms & 0.93 & 0.94 \\
\hline Activities & 0.94 & 0.94 \\
\hline Quality of life & 0.92 & 0.95 \\
\hline
\end{tabular}

Table 5. Test-retest reliability (reproducibility)

\begin{tabular}{|l|l|l|l|}
\hline & $\begin{array}{l}\text { Symptoms } \\
(\mathrm{n}=46)\end{array}$ & $\begin{array}{l}\text { Activities } \\
(\mathrm{n}=50)\end{array}$ & $\begin{array}{l}\text { QoL } \\
(\mathrm{n}=46)\end{array}$ \\
\hline Correlation coefficient & 0.90 & 0.95 & 0.90 \\
\hline
\end{tabular}

$\mathrm{QoL}=$ quality of life 
Table 6. Correlation between CAMPHOR scales and SF-36 section scores at Time 1

\begin{tabular}{|l|l|l|l|}
\hline & Symptoms & Activities & $\begin{array}{l}\text { Quality } \\
\text { of life }\end{array}$ \\
\hline SF-36 & & & \\
\hline Physical functioning & -0.54 & -0.74 & -0.62 \\
\hline $\begin{array}{l}\text { Physical role } \\
\text { limitations }\end{array}$ & -0.75 & -0.64 & -0.64 \\
\hline Bodily pain & -0.62 & -0.51 & -0.59 \\
\hline General health & -0.58 & -0.51 & -0.64 \\
\hline Vitality & -0.74 & -0.62 & -0.72 \\
\hline Social functioning & -0.69 & -0.60 & -0.79 \\
\hline $\begin{array}{l}\text { Emotional role } \\
\text { limitations }\end{array}$ & -0.51 & $-0.33^{*}$ & -0.49 \\
\hline $\begin{array}{l}\text { Emotional well- } \\
\text { being }\end{array}$ & -0.66 & -0.53 & -0.78 \\
\hline
\end{tabular}

All correlations significant at the 0.01 level (2-tailed) except where marked; *significant at the 0.05 level (2-tailed)

\section{Convergent validity}

Table 6 shows the association between CAMPHOR scale scores and those on the SF-36 sections at Time 1. CAMPHOR Symptoms were moderately highly associated with the SF-36 vitality and physical role limitations sections. As expected, CAMPHOR Activities were most strongly associated with physical functioning. CAMPHOR QoL was most closely re- lated to scores on the emotional well-being and social functioning sections of the SF-36.

\section{Known group validity}

There were statistically significant differences in scores on all three CAMPHOR scales related to both self-perceived disease severity (Fig. 1) and perceived overall health (Fig. 2).

\section{Association with demographic factors}

Table 7 shows CAMPHOR scores for patients grouped by gender and age (below versus above median age). Scale scores did not differ by gender.

A statistically significant difference between older and younger patients was found for the CAMPHOR Activities scale. Older patients scored higher on the scale than younger patients. This difference was not related to perceived severity of $\mathrm{PH}\left(\chi^{2}(49)=0.53\right.$; $\mathrm{p}=0.47)$. Similarly, no significant relation was found between age and perceived overall health $\left(\chi^{2}(50)=2.38\right.$; $\mathrm{p}=0.12)$.

\section{Discussion}

The CAMPHOR proved straightforward to adapt into Croatian and was found to be easily and quickly completed by, and relevant and comprehensive to, local $\mathrm{PH}$ patients. The adapted CAMPHOR demonstrated

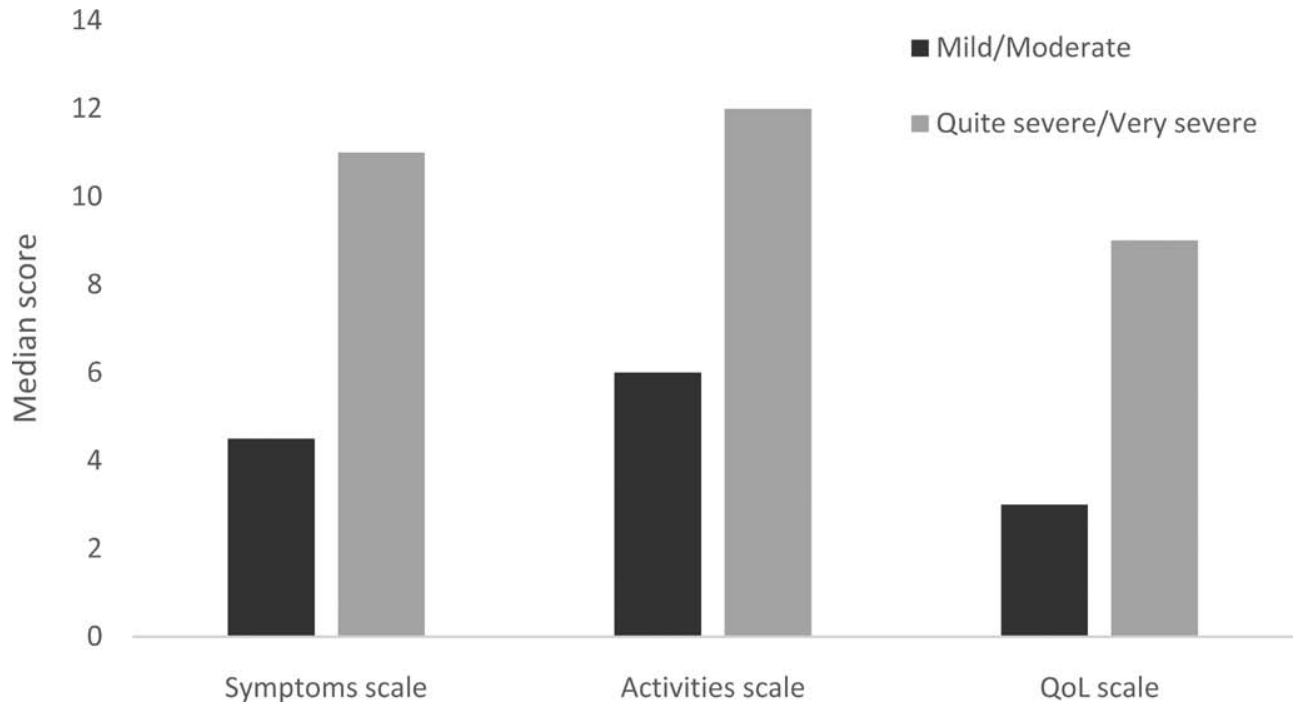

Fig. 1. Median CAMPHOR scale scores by perceived disease severity.

All comparisons statistically significant ( $\mathrm{p}<0.01 ; 2$-tailed); $\mathrm{QoL}=$ quality of life 


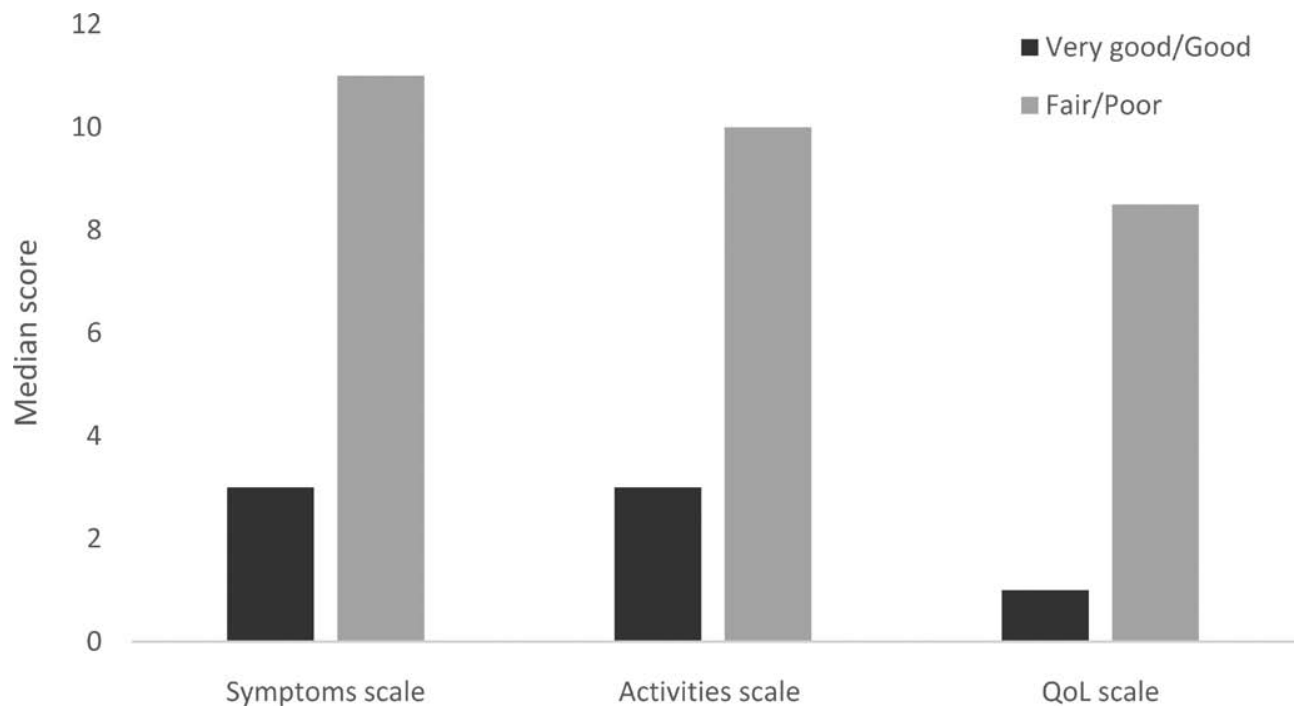

Fig. 2. Median CAMPHOR scale scores by perceived general health.

All comparisons statistically significant ( $<<0.001 ; 2$-tailed); QoL = quality of life

Table 7. CAMPHOR scale scores by gender and age group

\begin{tabular}{|l|l|l|l|l|l|l|}
\hline & & Symptoms & & Activities & & QoL \\
\cline { 2 - 7 } & $\mathrm{n}$ & Median (IQR) & $\mathrm{n}$ & Median (IQR) & $\mathrm{n}$ & Median (IQR) \\
\hline Gender & & & & & & \\
Male & 15 & $9(6-17)$ & 15 & $12(7-15)$ & 14 & $10(3-17)$ \\
Female & 32 & $9(3-13)$ & 35 & $7(4-11)$ & 34 & $5(2-11)$ \\
p & 47 & 0.42 & 50 & 0.14 & 48 & 0.26 \\
\hline Age & & & & & & \\
Below median & 25 & $7(4-13)$ & 25 & $6(3-9)$ & 24 & $5(1-10)$ \\
Above median & 22 & $10(6-18)$ & 25 & $12(7-17)$ & 24 & $7(4-16)$ \\
p & & 0.25 & & $<0.05$ & & 0.07 \\
\hline
\end{tabular}

$\mathrm{IQR}$ = interquartile range; $\mathrm{QoL}=$ quality of life

good psychometric properties, with excellent consistency and test-retest reliability. Tests of validity showed that CAMPHOR scale scores correlated as expected with SF-36 section scores and were able to distinguish between groups of patients who varied by perceived disease severity and general health.

Without careful adaptation, questionnaire items may be interpreted differently by local respondents or the instructions could cause problems. This study employed two translation panels ${ }^{24}$. This approach focuses on conceptual equivalence to the source measure rather than literal equivalence. Consequently, language versions are produced that are more directly comparable. Patients have rated translations produced by this dual-panel methodology as preferable to those developed using forward-backward translations ${ }^{29}$. Because of the numerous dialects in Croatia, it was important that the adaptation was expressed in simple, everyday language. Participants in the bilingual and lay panels were mainly from one region in Croatia, meaning it is possible that the translations would not be appropriate for all regional dialects. However, the psychometric validation stage included participants from throughout the country and no problems with the wording of items were found.

Given that elderly populations tend to have poor physical functioning, it is not surprising that differences in scores on the CAMPHOR Activities scale 
were found between older and younger patients. This finding could not be explained in terms of differences in patient-perceived disease severity or general health, suggesting that care should be taken when matching comparison groups in clinical studies.

A limitation of the study was that most of the participants in the bilingual panel were university students. Consequently, it is possible that the first translation produced may have been more appropriate to a younger population. However, any resulting issues were dealt with in the lay panel which consisted of people with a wider range of ages.

The Croatian CAMPHOR is one of many language adaptations that have been produced, all of which have been shown to have good psychometric properties. Results in this study compared well with those for the German ${ }^{30}$, Swedish ${ }^{31}$, Canadian ${ }^{32}$, United States $^{33}$, and Australian and New Zealand ${ }^{34}$ adaptations of the CAMPHOR. Use of the CAMPHOR in everyday practice may facilitate communication between clinicians and patients.

\section{Conclusion}

The newly developed Croatian CAMPHOR represents an accurate and reliable instrument for assessing both HRQL and QoL in Croatian PH patients. The new questionnaire will prove a valuable tool for application in clinical routine and for evaluating clinical and non-clinical interventions.

\section{References}

1. Galiè N, Humbert M, Vachiery JL, Gibbs S, Lang I, Torbicki A, et al.2015 ESC/ERS Guidelines for the diagnosis and treatment of pulmonary hypertension: The Joint Task Force for the Diagnosis and Treatment of Pulmonary Hypertension of the European Society of Cardiology (ESC) and the European Respiratory Society (ERS), endorsed Association for European Paediatric and Congenital Cardiology (AEPC), International Society of Heart and Lung Transplantation (ISHLT). Eur Heart J. 2015;46(4):903-75. doi: 10.1093/eurheartj/ehv317

2. Galiè N, Torbicki A, Barst R, Dartevelle P, Haworth S, Higenbottam T, et al. Guidelines on diagnosis and treatment of pulmonary arterial hypertension. The Task Force on Diagnosis and Treatment of Pulmonary Arterial Hypertension of the European Society of Cardiology. Eur Heart J. 2004;25:2243-78. doi: 10.1016/j.ehj.2004.09.014
3. Humbert M, Lau EM, Montani D, Jaïs X, Sitbon O, Simonneau $G$. Advances in therapeutic interventions for patients with pulmonary arterial hypertension. Circulation. 2014;130: 2189-208. doi: 10.1161/CIRCULATIONAHA.114.006974

4. McLaughlin VV, Badesch DB, Delcroix M, Fleming TR, Gaine SP, Galiè N, et al. End points and clinical trial design in pulmonary arterial hypertension. J Am Coll Cardiol. 2009; 54:S97-S107. doi: 10.1016/j.jacc.2009.04.007

5. Benza RL, Miller DP, Gomberg-Maitland M, Frantz RP, Foreman AJ, Coffey CS, et al. Predicting survival in pulmonary arterial hypertension: insights from the Registry to Evaluate Early and Long-Term Pulmonary Arterial Hypertension Disease Management (REVEAL). Circulation. 2010;122:164-72. 10.1161/CIRCULATIONAHA.109.898122

6. Galiè N, Olschewski H, Oudiz RJ, Torres F, Frost A, Ghofrani $\mathrm{HA}$, et al. Ambrisentan for the treatment of pulmonary arterial hypertension: results of the ambrisentan in pulmonary arterial hypertension, randomized, double-blind, placebo-controlled, multicenter, efficacy (ARIES) study 1 and 2. Circulation. 2008;117:3010-9.

doi: 10.1161/CIRCULATIONAHA.107.742510

7. Jaï X, D’Armini AM, Jansa P, Torbicki A, Delcroix M, Ghofrani HA, et al. Bosentan for treatment of inoperable chronic thromboembolic pulmonary hypertension: BENEFiT (Bosentan Effects in iNopErable Forms of chronIc Thromboembolic pulmonary hypertension), a randomized, placebo-controlled trial. J Am Coll Cardiol. 2008;52:2127-34. doi: 10.1016/j. jacc.2008.08.059

8. Simonneau G, Rubin LJ, Galiè N, Barst RJ, Fleming TR, Frost $\mathrm{AE}$, et al. Addition of sildenafil to long-term intravenous epoprostenol therapy in patients with pulmonary arterial hypertension: a randomized trial. Ann Intern Med. 2008;149: 521-30. doi: 10.7326/0003-4819-149-8-200810210-00004

9. Galiè N, Brundage BH, Ghofrani HA, Oudiz RJ, Simonneau G, Safdar Z, et al. Tadalafil therapy for pulmonary arterial hypertension. Circulation. 2009;119:2894-903. doi: 10.1161/CIRCULATIONAHA.108.839274

10. Olschewski H, Simonneau G, Galiè N, Higenbottam T, Naeije $\mathrm{R}$, Rubin LJ, et al. Inhaled iloprost for severe pulmonary hypertension. N Engl J Med. 2002;347:322-9. doi: 10.1056/NEJMoa020204

11. Barst RJ, Rubin LJ, Long WA, McGoon MD, Rich S, Badesch $\mathrm{DB}$, et al. A comparison of continuous intravenous epoprostenol (prostacyclin) with conventional therapy for primary pulmonary hypertension. N Engl J Med. 1996;334:296-302. doi: 10.1056/NEJM199602013340504

12. Kaplan RM, Anderson JP, Wu AW, Matthews WC, Kozin F, Orenstein D. The Quality of Well-being Scale: applications in AIDS, cystic fibrosis, and arthritis. Med Care. 1989;27(3): S27-43.

13. Doward LC, Meads DM, Thorsen H. Requirements for quality of life instruments in clinical research. Value H ealth. 2004; 7:S13-S16. doi: 10.1111/j.1524-4733.2004.7s104.x 
14. Brazier J, Harper R, Jones NM, O'cathain A, Thomas KJ, Usherwood T, et al. Validating the SF-36 health survey questionnaire: new outcome measure for primary care. BMJ. 1992; 305:160-4. doi: 10.1136/bmj.305.6846.160

15. Nerenz DR, Repasky DP, Whitehouse FW, Kahkonen M. Ongoing assessment of health status in patients with diabetes mellitus. Med Care. 1992;30(S5):S112-23.

16. Dorman P, Slattery J, Farrell B, Dennis M, Sandercock P. Qualitative comparison of the reliability of health status assessments with the EuroQoL and SF-36 questionnaires after stroke. Stroke. 1998;29:63-8. doi: 10.1161/01.STR.29.1.63

17. Delcroix M, Howard L. Pulmonary arterial hypertension: the burden of disease and impact on quality of life. Eur Respir Rev Off J Eur Respir Soc. 2015 Dec;24(138):621-9. doi: 10.1183/16000617.0063-2015

18. Vanhoof J, Delcroix M, Vandevelde E, Denhaerynck K, Wuyts $\mathrm{W}$, Belge $\mathrm{C}$, et al. Emotional symptoms and quality of life in patients with pulmonary arterial hypertension. J Heart Lung Transplant Off Publ Int Soc Heart Transplant. 2014 Aug; 33(8):800-8. doi: 10.1016/j.healun.2014.04.003

19. McKenna SP, Doughty N, Meads DM, Doward LC, PepkeZaba J. The Cambridge Pulmonary Hypertension Outcome Review (CAMPHOR): a measure of health-related quality of life and quality of life for patients with pulmonary hypertension. Qual Life Res. 2006;15(1):103-15. doi: 10.1007/s11136005-3513-4

20. Hunt SM, McKenna SP. The QLDS: a scale for the measurement of quality of life in depression. Health Policy. 1992; 22(3):307-19. doi: 10.1016/0168-8510(92)90004-UP

21. Twiss J, McKenna S, Ganderton L, Jenkins S, Ben-Lamri M, Gain K, et al. Psychometric performance of the CAMPHOR and SF-36 in pulmonary hypertension. BMC Pulm Med. 2013;13(1):45-52. doi: 10.1186/1471-2466-13-45

22. Yorke J, Corris P, Gaine S, Gibbs JS, Kiely DG, Harries C, et al. emPHasis-10: development of a health-related quality of life measure in pulmonary hypertension. Eur Respir J. 2013;43 (4):1106-13. doi: 10.1183/09031936.00127113.

23. McCollister D, Shaffer S, Badesch DB, Filusch A, Hunsche E, Schüler R, et al. Development of the Pulmonary Arterial Hypertension-Symptoms and Impact (PAH-SYMPACT ${ }^{\circledR}$ ) questionnaire: a new patient-reported outcome instrument for PAH. Respir Res. 2016;17(1):72. doi: 10.1186/s12931-016-0388-6
24. Hunt SM, Alonso J, Bucquet D, Niero M, Wiklund I, McKenna SP. Cross-cultural adaptation of health measures. Health Policy. 1991;19:33-44. doi: 10.1016/0168-8510(91)90072-6

25. Jureša $V$, Ivanković $D$, Vuletić $G$, Babić-Banaszak A, Srček I, Mastilica M, et al. The Croatian Health Survey - SF-36 general quality of life assessment. Coll Antropol. 2000;241:69-78.

26. Streiner DL, Norman GR. Health Measurement Scales: A Practical Guide to Their Development and Use. $2^{\text {nd }}$ edn. New York: Oxford University Press; 1995.

27. Weiner EA, Stewart BJ. Assessing Individuals. Boston: Little Brown; 1984.

28. IBM Corp. Released 2014. IBM SPSS Statistics for Windows, Version 23.0. Armonk, NY: IBM Corp.

29. Hagell P, Hedin PJ, Meads DM, Nyberg L, McKenna SP. Effects of method of translation of patient-reported health outcome questionnaires: a randomized study of the translation of the Rheumatoid Arthritis Quality of Life (RAQoL) instrument for Sweden. Value Health. 2010;13(4):424-30. doi: 10.1111/j.1524-4733.2009.00677.x

30. Cima K, Twiss J, Speich R, McKenna SP, Grunig E, Kahler CM, et al. The German adaptation of the Cambridge Pulmonary Hypertension Outcome Review (CAMPHOR). Health Qual Life Outcomes. 2012;10:110-7. doi: 10.1186/1477-7525-10-110

31. Selimovic N, Rundqvist B, Kjork E, Viriden J, Twiss J, McKenna SP. Adaptation and validation of the Cambridge Pulmonary Hypertension Outcome Review for Sweden. Scand J Public Health. 2012;40:777-83. doi: 10.1177/1403494812464445

32. Coffin D, Duval K, Martel S, Granton J, Lefebvre MC, Meads DM, et al. Adaptation of the Cambridge Pulmonary Hypertension Outcome Review (CAMPHOR) into French-Canadian and English-Canadian. Can Respir J. 2008;15:77-83. doi: $10.1155 / 2008 / 767126$

33. Gomberg-Maitland M, Thenappan T, Rizvi K, Chandra S, Meads DM, McKenna SP. United States validation of the Cambridge Pulmonary Hypertension Outcome Review (CAMPHOR). J Heart Lung Transplant. 2008;27:124-30. doi: 10.1016/j.healun.2007.10.004

34. Ganderton L, Jenkins S, McKenna SP, Gain K, Fowler R, Twiss $\mathrm{J}$, et al. Validation of the Cambridge Pulmonary Hypertension Outcome Review (CAMPHOR) for the Australian and New Zealand population. Respirology. 2011;16:1235-40. doi: 10.1111/j.1440-1843.2011.02030.x 


\title{
Sažetak \\ HRVATSKA PRILAGODBA I VREDNOVANJE UPITNIKA THE CAMBRIDGE PULMONARY HYPERTENSION OUTCOME REVIEW (CAMPHOR)
}

\author{
A. Hečimović, A. Heaney, S.P. McKenna, L. Basara, M. Jakopović, A. Vukić Dugac, G. Redžepi, \\ C. Rotim, M. Samaržija, N. Jokić-Begič i S. Popović-Grle
}

Plućna hipertenzija je kronična bolest koja značajno narušava kvalitetu života. The Cambridge Pulmonary Hypertension Outcome Review (CAMPHOR) je prvi upitnik specifičan za ovu bolest kojim bolesnici s plućnom hipertenzijom smoprocjenjuju simptome, funkcionalni status i kvalitetu života. Cilj ove studije bio je prilagoditi i vrednovati CAMPHOR za uporabu u Republici Hrvatskoj. Prilagodba je postupak koji uključuje tri koraka: prijevod (dvojezični panel i panel laika), kognitivno ispitivanje i psihometrijsko vrednovanje. $U$ daljnjem tijeku ispitivanje je provedeno na 50 bolesnika kako bi se ispitala pouzdanost i valjanost adaptiranih ljestvica. Sve tri ljestvice hrvatske verzije CAMPHOR-a pokazale su izvrsnu unutarnju konzistenciju (Simptomi = 0,93; Aktivnosti = 0,95; Kvaliteta života $=0,92)$ i ponovljivost (Simptomi =0,90; Aktivnosti = 0,95; Kvaliteta života $=0,92$ ). Korelacija sa česticama SF-36 potvrdila je strukturnu valjanost ljestvica CAMPHOR-a. Prema rezultatima ljestvica moguće je razlikovati ispitanike grupirane prema samoprocijenjenom općem zdravstvenom stanju i težini bolesti, čime je dokazana valjanost upitnika za definirane skupine. Hrvatska inačica CAMPHOR-a je valjan i pouzdan upitnik za primjenu u svakodnevnom kliničkom radu i kliničkim ispitivanjima.

Ključne riječi: Hipertenzija, plućna; Kvaliteta života; Hrvatska; Reproducibilnost rezultata; Ankete i upitnici 